\title{
Phytoplankton community and trophic status assessment of a newly impounded sub-tropical reservoir: case study of the Nam Theun 2 Reservoir (Lao PDR, Southeast Asia)
}

\section{Étude de la communauté phytoplanctonique et évaluation du statut trophique d'un réservoir sub-tropical nouvellement mis en eau : étude du réservoir hydroélectrique de Nam Theun 2 (Laos, Asie du Sud-Est)}

\author{
J. Martinet ${ }^{(1)}$, P. Guédant ${ }^{(1)}$, S. Descloux ${ }^{(2)}$ \\ (1) Nam Theun 2 Power Company Limited (NTPC), Environment \& Social Division - Water Quality and \\ Biodiversity Dept. - Gnommalath Office, PO Box 5862, Vientiane, Lao PDR \\ (2) EDF, Hydro Engineering Centre - Savoie Technolac, 73373 Le Bourget du Lac, France \\ stephane.descloux@edf.fr
}

\begin{abstract}
Phytoplankton community and its relationships with the physico-chemical variables were studied in the newly impounded Nam Theun 2 sub-tropical Reservoir, located in Lao PDR (Southeast Asia). Samples were collected on a monthly basis from March 2009 to December 2012 within the euphotic zone of five sampling sites. One hundred and eighty taxa were identified during this study. A significant seasonal effect on the NT2 phytoplanktonic community was related to water temperature, precipitation and water level. Dinoflagellates and green algae mainly contributed to phytoplanktonic biomasses usually highest in June with a maximum of $3 \times 10^{3} \mu \mathrm{g} \mathrm{C} . \mathrm{L}^{-1}$. Both biomasses and Chl-a exhibited similar variation with significant relationship. Moreover, total phytoplankton biomass has also a significant correlation with the Secchi depth suggesting that water transparency might be dictated by phytoplankton biomass. The trophic status was assessed according to the nutrients concentrations, Secchi depth and Chlorophyll a (Chl a) (OECD classification and AARL-PC scores) and the phytoplankton composition (AARL-PP scores). This study revealed the suitability of Chl-a, phytoplankton biomass and phytoplankton composition for assessing the trophic state of a young and sub-tropical reservoir. The results illustrated an oligotrophication of the NT2 Reservoir at the end of period of study. Consequently, this approach might be recommended to follow the evolution of the trophic status of a young and sub-tropical reservoir.
\end{abstract}

Key words - species composition, phytoplankton biomass, trophic status, young subtropical reservoir, impoundment 
Résumé - La composition phytoplanctonique et ses relations avec les paramètres physicochimiques ont été étudiées dans le réservoir subtropical de Nam Theun 2 (Laos, Asie du SudEst) peu après sa mise en eau. Les campagnes d'échantillonnage mensuelles se sont déroulées entre mars 2009 et décembre 2012. Les échantillons ont été collectés dans la zone euphotique de cinq stations du réservoir. Plus de 180 taxons ont été identifiés lors de cette étude. L'effet saisonnier sur les biomasses est significatif, expliqué principalement par la température et les précipitations. Les Dinoflagellés et les algues vertes ont contribué principalement au pic de biomasse phytoplanctonique généralement mesuré en juin, atteignant $3 \times 10^{3} \mu \mathrm{g} \mathrm{C} . \mathrm{L}^{-1}$. Les concentrations en Chlorophylle a et la biomasse totale sont fortement corrélées. En outre, la corrélation significative entre la biomasse totale et la profondeur de Secchi suggère que la transparence de l'eau pourrait être influencée par la communauté phytoplanctonique. Le statut trophique a été évalué en fonction des concentrations en nutriments, de la profondeur du disque de Secchi, de la Chlorophylle a (Chl a) (classification OCDE et AARL-PC scores) et de la composition phytoplanctonique (AARL-PP scores). Cette étude a révélé la pertinence dans l'utilisation de la $\mathrm{Chl} a$, de la biomasse et de la composition phytoplanctonique pour l'évaluation du statut trophique d'un jeune réservoir subtropical. Au cours de la période d'étude, les résultats ont illustré une oligotrophisation du Réservoir NT2. En conséquence, cette approche doit être prise en compte afin de suivre l'évolution du statut trophique d'un jeune réservoir subtropical.

Mots clés - composition spécifique, biomasse phytoplanctonique, statut trophique, jeune réservoir subtropical, mise en eau

\section{INTRODUCTION}

Man-made reservoirs have distinct characteristics compared to natural lakes inherent to their specific features and the management of their water level (ASLO, 1990; Thornton et al., 1990). The impoundment of a reservoir resulted in a new hydrosystem characterized as a lentic aquatic habitat. Phytoplankton usually becomes the main primary producer of the pelagic zone influencing the whole aquatic food web of this new lentic ecosystem (Reynolds, 2006). Numerous studies have described the ecology of phytoplankton community in lakes and reservoirs regardless the latitude (Reynolds, 1984; Happey-Wood, 1988; Padisák, 2003; Sarmento \& Descy, 2008) and focusing on undesirable effects such as eutrophication (Crossetti
\& Bicudo, 2008) or harmful algal bloom (Smith, 1983; Codd et al., 2005). Nevertheless, European studies have demonstrated the major role in these phenomena of the physical structure of the reservoir and of the nutrients availability (Naselli-Flores, 2000; Padisák et al., 2006; Reynolds, 2006; Anneville et al., 2008). Both factors are, directly and indirectly, the most important variables influencing the phytoplankton composition variability in terms of abundance and composition (Harris, 1986; Tundisi et al., 1999; Becker et al., 2010; Rigosi \& Rueda, 2012).

Thornton et al. (1990) also concluded that tropical and sub-tropical reservoirs are aquatic ecosystems in which the synergy between physical, chemical and biological variables is strongly controlled by hydrological regime 
(e.g. the upstream river inputs and periodic dewatering). Because the succession of phytoplankton community is strongly linked to meteorological conditions, patterns in temperate ecosystems differ from those of tropical waters (Wetzel, 2001). Furthermore, other studies have described the meteorological variables such as rainfall, wind and temperature as one of the second factors controlling phytoplankton habitat (Dos Santos \& Calijuri, 1998; Melo \& Huszar, 2000; Calijuri et al., 2002). Although phytoplankton studies in tropical reservoirs generally emphasize community successions as well as the key parameters structuring the assemblages (Lewis, 2000; Calijuri \& Dos Santos, 2001; Crossetti \& Bicudo, 2005; Sarmento et al., 2008), very few studies have dealt with newly impounded reservoirs (Zeng et al., 2006; Feinpend et al., 2013). For instance, Dai et al. (2010) have shown that during the early stage of the Chinese Three Gorges Reservoir, Chlorophyta, Diatoms and Cyanophyta represented respectively $55 \%, 24 \%$ and $10 \%$ of the total species composition and that their dynamic were mainly driven by strong vertical gradients of temperature and density (Zhu et al., 2013).

Thanks to its capacity to integrate environmental changes within a short term period, phytoplankton is often used in large monitoring programs to complete the approach of trophic status classification scheme based on total phosphate, chlorophyll a values as well as water transparency (OECD, 1982). Phytoplankton biomasses and chlorophyll $a$ are the metrics generally used until now to assess the trophic status of lakes and reservoirs (Büsing, 1998; Díaz-Pardo et al., 1998). More recently, the water quality assessment for European and North American lakes and reservoirs was successfully investigated using phytoplankton species composition (Water Framework Directive, 2000; Reynolds, 2006; Crossetti \& Bicudo, 2008; Poikane et al., 2011). Since the last decades scientists of Alpine and Mediterranean ecoregions have successfully developed and harmonized assessment methods using phytoplankton composition for water quality management (Brettum, 1989; Catalan et al., 2003; Salmaso et al., 2006). In Southeast Asia, Peerapornpisal et al. (2004) set out a score approach for trophic status assessment within Thai reservoirs. The method is based on the physico-chemical parameters (AARL-PC) and on the phytoplankton composition (AARL-PP). Because such investigations were developed within the same ecoregions as the study area, we therefore contend that such an approach could be applied to our study.

This study was conducted in the Nam Theun 2 (NT2) Reservoir (Lao PDR, Southeast Asia), for four years since its impoundment. We described the phytoplankton community with the analysis of 2 metrics (biomass, and $\mathrm{Chl}$ a) and identified the driving factors structuring phytoplankton dynamic over the four years after impoundment. The study also assessed the trophic status of this newly impounded reservoir using a panel of indicators based on water physicochemical features, chlorophyll a, Secchi depth and phytoplankton composition. 


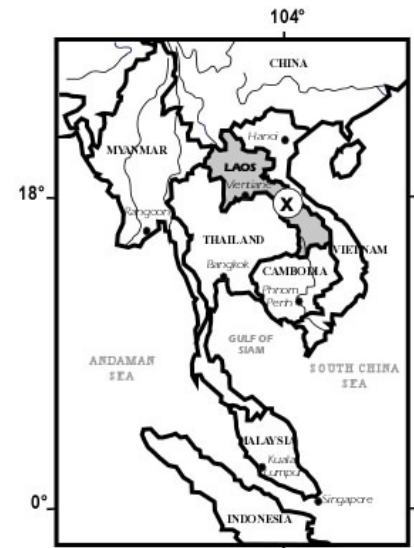

(a)

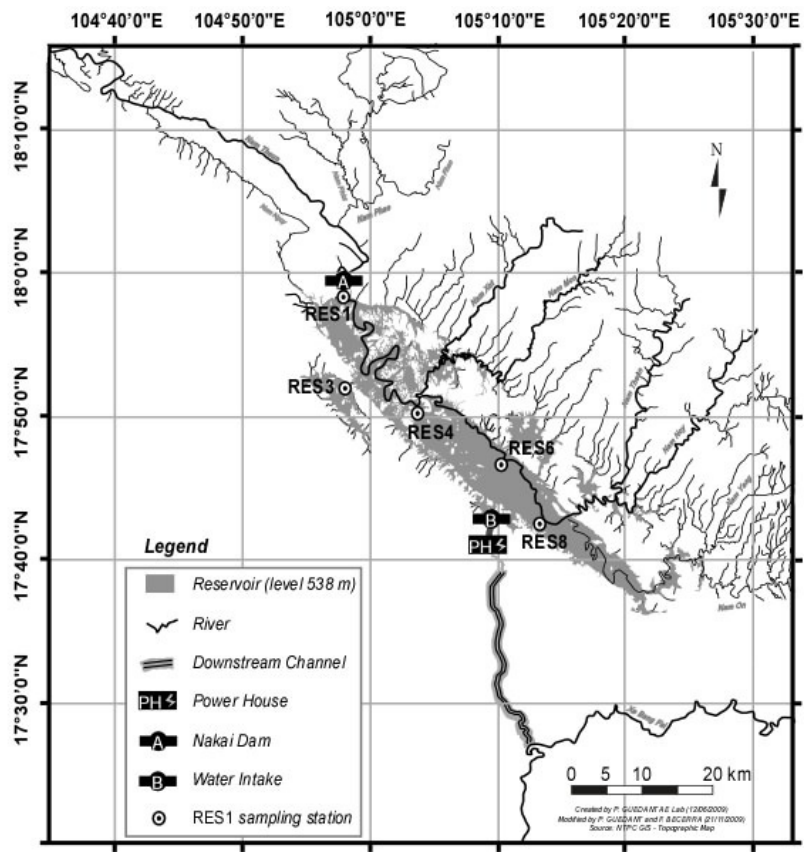

Fig. 1. (a) Map of the Nam Theun 2 Reservoir in Lao PDR, (b) map of the NT2 Reservoir and of the five sampling sites RES1, RES3, RES4, RES6 and RES8.

Fig. 1. (a) Carte du réservoir Nam Theun 2 au Laos, (b) carte du réservoir de NT2 et des cinq sites d'échantillonnage RES1, RES3, RES4, RES6 et RES8.

\section{MATERIALS \& METHODS}

\subsection{Study area}

The NT2 hydroelectric Reservoir is located on the Nakai Plateau (Khammouane Province) in Lao PDR (Fig. 1a). It covers a surface of about $489 \mathrm{~km}^{2}$ at its full supply level. Its maximum depth is $38 \mathrm{~m}$ at the Dam site with an average depth of $11 \mathrm{~m}$ leading to a total volume of $3.9 \mathrm{~km}^{3}$. The reservoir was impounded between May 2008 and February 2009 and the commercial operation started in April 2010. Physico-chemical water quality parameters and phytoplankton communities were monitored since March 2009 , few months after the beginning of the impoundment. Once commercial operation started, the reservoir level presented a mean annual drawdown of $8.6 \mathrm{~m}(\mathrm{~min} 7.6 \mathrm{~m}$ in 2010 and $\max 9.5 \mathrm{~m}$ in 2011).

The climate is sub-tropical and the reservoir is submitted to a monsoon regime. The warm-wet season runs from June to October where $90 \%$ of annual precipitations occur and lead to an important natural seasonal mixing of the water body. The warm-dry season runs from February to June. The cooldry season runs from October to February. The NT2 Reservoir is defined as a shallow monomictic sub-tropical reservoir and the stratification sets during the warm dry season (Chanudet et al., 
2012). The limnological background data of the NT2 Reservoir are described in detail in Descloux et al. (same issue).

\subsection{Sampling strategy}

At the same location, phytoplankton and water quality parameters were routinely measured on a monthly basis from March 2009 to December 2012 for each of the five sampling sites (RES1: Dam site, RES3: flooded forest, RES4, RES6 and RES8: former riverbed; Fig. 1b).

On the field, a multi-parameter probe (Quanta, Hydrolab) was used to measure physico-chemical water quality parameters (i.e. water temperature, dissolved oxygen and saturation, $\mathrm{pH}$ and conductivity) at the five sampling sites. Parameters were measured every $0.5 \mathrm{~m}$ within the five first metres of the uppermost (including the euphotic zone) and every $1 \mathrm{~m}$ below, to describe vertical profiles.

Phytoplankton samples were collected in the euphotic zone (Zeu) defined by 2.5 times the Secchi disk depth (Poikane, 2009). The sampling strategy followed an integrated method with 1 litre of water collected with a Niskin bottle at 5 equidistant depths between the surface and the bottom of the euphotic layer. From the 5 mixed litres, one litre is collected for chlorophyll a (Chl-a) analysis by spectrophotometry (APHA standards, 1995), $500 \mathrm{~mL}$ were collected and immediately preserved with a Lugol's solution (Vollenweider, 1969) for phytoplankton identification and numeration and $250 \mathrm{~mL}$ were collected for chemistry analyses. Water samples were preserved in a cool box until the analyses (some hours after sampling).

\subsection{Sample analysis}

Chemistry analyses were done according to the American Standards for Water Quality (APHA standards, 1995). Dissolved Organic Carbon (DOC) was analysed with IR Spectrophotometry after acidification and combustion (limit of detection of $0.5 \mathrm{mg} \cdot \mathrm{L}^{-1}$ ). For the Total Suspended Solids (TSS), gravimetric method was used after filtration at $1.2 \mu \mathrm{m}$ and drying 2 hours at 103-105 ${ }^{\circ} \mathrm{C}$. Total Nitrogen (TN) and Total Phosphorous (TP) were analysed by spectrophotometry whereas nitrate $\left(\mathrm{NO}_{3}-\mathrm{N}\right)$ and Soluble Reactive Phosphorus concentrations $\left(\mathrm{PO}_{4}-\mathrm{P}\right)$ were determined using HPLC (Metrohm 861 Advanced Compact IC after filtration at $0.45 \mu \mathrm{m})$. Ammonia-nitrogen $\left(\mathrm{NH}_{3}-\mathrm{N}\right)$ was calculated from $\mathrm{NH}_{4}-\mathrm{N}$ data, combined with $\mathrm{pH}$ and water temperature. For Biological Oxygen Demand at 5 days $\left(\mathrm{BOD}_{5}\right)$ and the Chemical Oxygen Demand (COD), the Dissolved Oxygen (DO) is measured by oxygen membrane probe after 5 days of incubation at $20^{\circ} \mathrm{C}$ (see Chanudet et al., same issue for a thorough detail of the limit of detection).

Phytoplankton identification and numeration were carried out under inverted microscope (objective $\mathrm{x} 40$ ) with sedimentation chambers (Utermöhl, 1958). The transect method (diameter) were achieved for the analyses until reaching more than 400 units (NF EN 15204, AFNOR 2006). Geometric shape was assigned to each species. The appropriate cell volume was calculated 
Table I. Definition of the trophic status of the reservoir according to Total Phosphorous (TP), Chlorophyll a concentrations and Secchi depth (from the OECD, 1982).

Tableau I. Détermination du statut trophique du réservoir selon les concentrations du phosphore total, de la Chlorophylle a et de la profondeur de Secchi (d'après l'OCDE, 1982).

\begin{tabular}{|c|c|c|c|c|}
\hline & \multicolumn{4}{|c|}{ TROPHIC STATUS } \\
\hline $\begin{array}{c}\text { Variables } \\
\text { (Annual means) }\end{array}$ & Oligotrophic & Mesotrophic & Eutrophic & Hypereutrophic \\
\hline $\begin{array}{c}\text { Total phosphorous } \\
\left(\mathrm{mg}_{\mathrm{L}}^{-1}\right)\end{array}$ & $\leq 0.010$ & 0.010 to 0.035 & 0.035 to 0.100 & $\geq 0.100$ \\
\hline $\begin{array}{c}\text { Chlorophyll } a \\
\left(\mu \mathrm{g} \mathrm{L}^{-1}\right)\end{array}$ & $\leq 2.5$ & 2.5 to 8 & $8-25$ & $\geq 25$ \\
\hline $\begin{array}{c}\text { Secchi depth } \\
(\mathrm{m})\end{array}$ & $\geq 6$ & 6 to 3 & 3 to1.5 & $\leq 1.5$ \\
\hline
\end{tabular}

from its dimension (length, width and diameter). It was defined on the measurement of at least 30 individuals (Hillebrand et al., 1999). Algal biovolume was converted into phytoplankton biomass expressed in carbon unit for each class assuming a specific gravity of $1.00 \mathrm{~g} / \mathrm{cm}^{3}$ (Wetzel \& Lickens, 2000). Identification was based on specialized taxonomic literature (Bourrelly, 1981, 1985, 1990; Starmach, 1972, 1974, 1983; Hindák, 1984, 1988, 1990).

\subsection{Data analysis}

The evaluation of the NT2 Reservoir trophic status was assessed combining different methods. Total Phosphate (TP), Chlorophyll a (Chl-a) and Secchi depth were compared with the trophic classification from OECD (1982). Boundaries between each trophic status are illustrated in Table I. Phytoplankton biomass metrics values (chlorophyll $a$ and phytoplankton biovolume) were available after sample analysis but further calculations were required for other indicators. For Thai region, Peerapornpisal et al. (2004), set out a method for trophic status assessment, through an index based on the physico-chemical parameters measured in the surface water (DO, $\mathrm{BOD}_{5}$, conductivity, $\mathrm{NO}_{3}-\mathrm{N}$, $\mathrm{NH}_{3}-\mathrm{N}$ and TP): the AARL-PC Score (Applied Algal Research Laboratory, Tab. II). This index is defined by the addition of the scores obtained by each parameters corresponding to their range of values. The AARL-PP Score was defined by Wetzel (2001) and Peerapornpisal et al. (2007) according to phytoplankton composition. This index is obtained by score values of the dominant phytoplankton genera representing at least $5 \%$ of the total biomasses. Each species has a specific score according to its preferential trophic status environment. The classification defines six categories of trophic status. Minimum scores (0-1) express oligotrophy whereas high score (9-10) express hypereutrophy.

\subsection{Statistical methods}

Principal Component Analysis (PCA) was performed by using XLSTAT software to establish the relationships between abiotic variables (DOC, total 
Table II. AARL-PC score according to the values of the main physico-chemical parameters (from Peerapornpisal et al., 2004).

Tableau II. AARL-PC Score selon les valeurs de principaux paramètres physico-chimiques (d'après Peerapornpisal et al., 2004).

\begin{tabular}{|c|c|c|c|c|c|c|}
\hline $\begin{array}{l}\text { AARL-PC } \\
\text { score }\end{array}$ & DO (mg. $\left.\mathrm{L}^{-1}\right)$ & BOD $_{5}\left(\mathrm{mg} \mathrm{L}^{-1}\right)$ & $\begin{array}{c}\text { Conductivity } \\
\left(\mu \mathrm{S} . \mathrm{cm}^{-1}\right)\end{array}$ & $\begin{array}{c}\mathrm{NO}_{3}-\mathrm{N} \\
\left(\mathrm{mg}^{-\mathrm{L}^{-1}}\right)\end{array}$ & $\begin{array}{c}\mathrm{NH}_{3}-\mathrm{N} \\
\left(\mathrm{mg}^{-\mathrm{L}^{-1}}\right)\end{array}$ & P-PO4 (mg.L $\left.{ }^{-1}\right)$ \\
\hline 0.1 & $>8$ & $<0.25$ & $<10$ & $<0.05$ & $<0.1$ & $<0.05$ \\
\hline 0.2 & $7-8$ & $0.25-0.5$ & $10-20$ & $0.05-0.1$ & $0.1-0.2$ & $0.05-0.2$ \\
\hline 0.3 & $6-7$ & $0.5-1$ & $20-40$ & $0.1-0.3$ & $0.2-0.4$ & $0.2-0.4$ \\
\hline 0.4 & $5-6$ & $1-2$ & $40-70$ & $0.3-0.8$ & $0.4-0.8$ & $0.4-0.8$ \\
\hline 0.5 & $4-5$ & $2-4$ & $70-100$ & $0.8-1.5$ & $0.8-1.5$ & $0.8-1.5$ \\
\hline 0.6 & $3-4$ & $4-10$ & $100-150$ & $0.5-3.0$ & $1.5-3.0$ & $1.5-3.0$ \\
\hline 0.7 & $2-3$ & $10-20$ & $150-230$ & $3.0-10.0$ & $3.0-5.0$ & $3.0-5.0$ \\
\hline 0.8 & $1-2$ & $20-40$ & $230-400$ & $10.0-20.0$ & $5.0-10.0$ & $5.0-10.0$ \\
\hline 0.9 & $0.5-1$ & $40-80$ & $400-550$ & $20.0-40.0$ & $10.0-20.0$ & $10.0-20.0$ \\
\hline 1.0 & $<0.5$ & $>80$ & $>550$ & $>40.0$ & $>20.0$ & $>20.0$ \\
\hline
\end{tabular}

phosphate, total nitrate, euphotic zone, reservoir water level, rain and water temperature) having the highest influence on the phytoplankton community (average total biomasses and average cellular concentrations). For the ordination analysis, we transformed the abiotic and phytoplankton data by $\log _{\mathrm{x}}+1$.

The responses of the phytoplankton metrics (Chl-a, biomass) to physicochemical parameters (TP, Secchi depth) and the index (AARL-PC and AARL-PP Scores) were analysed with correlation tests. Correlation were performed for each pair of metrics (in Molina Navarro et al., 2014) obtaining $\mathrm{R}^{2}$ and $\mathrm{p}$-value (Spearman test).

\section{RESULTS}

\subsection{Physical and chemical parameters}

Monthly average data of all sampling stations are presented for the three sea- sons (Cool dry: CD, warm dry: WD and warm wet: WW seasons) from 2009 to 2012 (Tab. III). For both water temperature and $\mathrm{pH}$, average values were higher in the WD season. Water temperature was approximately $8{ }^{\circ} \mathrm{C}$ higher than in the coolest month (January) whatever the year. The water was slightly acid. No general annual trend can be observed for conductivity. It was relatively low ranging from $28.7 \mu S . \mathrm{cm}^{-1}$ in January 2009 to $17.1 \mu \mathrm{S} . \mathrm{cm}^{-1}$ in June 2012. The nitrate concentrations $\left(\mathrm{NO}_{3}{ }^{-} \mathrm{N}\right)$ were generally low over the study period. The highest values were found after the impoundment and during the WW season with an average of $0.36 \mathrm{mg} \cdot \mathrm{L}^{-1} \cdot \mathrm{NH}_{3}-\mathrm{N}$ concentrations were under the limit of detection $\left(<0.01 \mathrm{mg} \cdot \mathrm{L}^{-1}\right)$. Soluble Reactive Phosphorus concentrations $\left(\mathrm{PO}_{4}-\mathrm{P}\right)$ reached the highest values in 2009 during the CD and WD seasons (with $0.06 \mathrm{mg}^{\mathrm{L} \mathrm{L}^{-1}}$ ). Afterwards, they were below the detection limit $\left(<0.1 \mathrm{mg} \cdot \mathrm{L}^{-1}\right)$. 


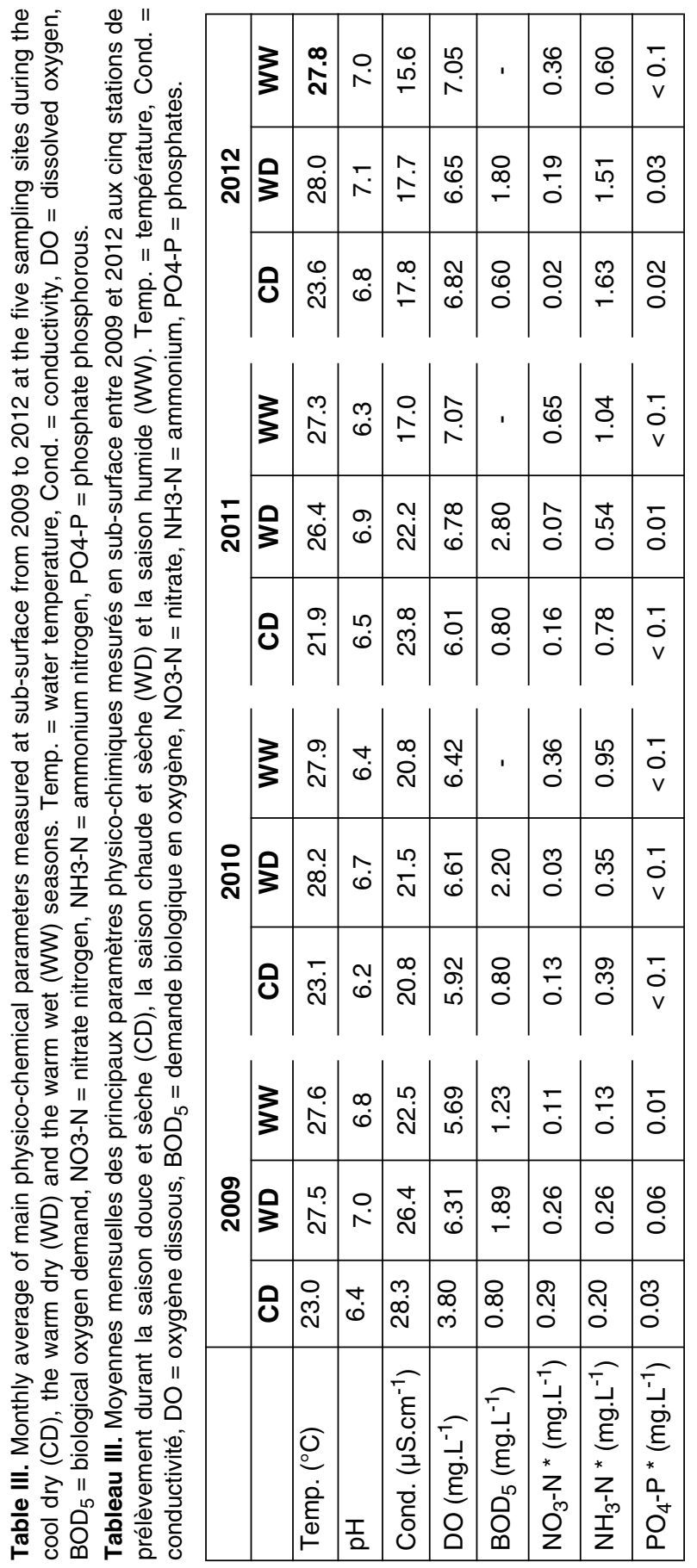




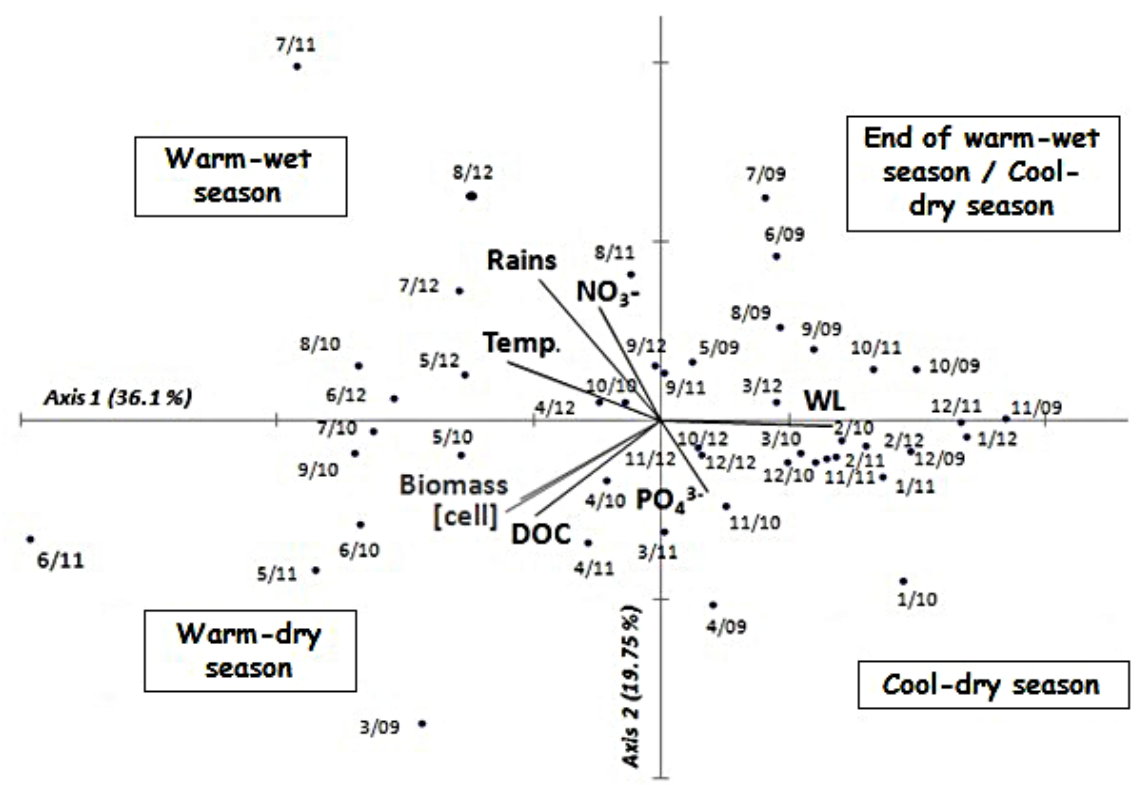

Fig. 2. Biplot of PCA for the mean values of eight variables measured at the 5 sampling sites within the reservoir for the study period. Abbreviations: Biomass: phytoplankton total biomass; [cell]: cellular concentration; DOC: dissolved organic carbon; $\mathrm{PO}_{4}{ }^{3-}$ : orthophosphate; $\mathrm{NO}_{3}{ }^{-}$: nitrate; WL: reservoir water level; Rains: rain; Temp.: water temperature.

Fig. 2. Biplot de l'ACP pour les valeurs moyennes de huit variables mesurées aux cinq stations de prélèvement sur la période d'étude. Abréviations : Biomass : biomasse totale du phytoplancton ; [cell] : concentration cellulaire ; DOC : carbone organique dissous ; $\mathrm{PO}_{4}{ }^{3-}$ : orthophosphate ; $\mathrm{NO}_{3}{ }^{-}$: nitrate ; WL : niveau du réservoir ; Rain : pluie ; Temp. : température de l'eau.

\subsection{Relationships between phytoplankton and environmental variables}

Principal Component Analysis (PCA), using eight quantitative variables (phytoplankton total biomass, cellular concentration, DOC, phosphate, nitrate, reservoir water level, rain and water temperature), explain $55.8 \%$ of the data variability in the two first axis (Fig. 2). The eigenvalues for axes 1 and 2 are 2.89 and 1.58 respectively. The most important variables for axis 1 ordination $(36.1 \%)$ were temperature, DOC and water level. These results indicated a seasonal gradient and underlined the importance of the hydrological regime. Axis 1 discrimates the warmest period from the coolest one. On the positive side of axis 1 , the sampling units of cool season are correlated with highest water level. On its negative side, the sampling units of WD and WW seasons are correlated with higher values of water temperature, rain, DOC and phytoplankton biomass. Regarding the axis $2(19.75 \%)$ rain and nitrate concentration were the most important variables. This second axis separates the wet months from the dry ones. Consequently four periods could be defined according 


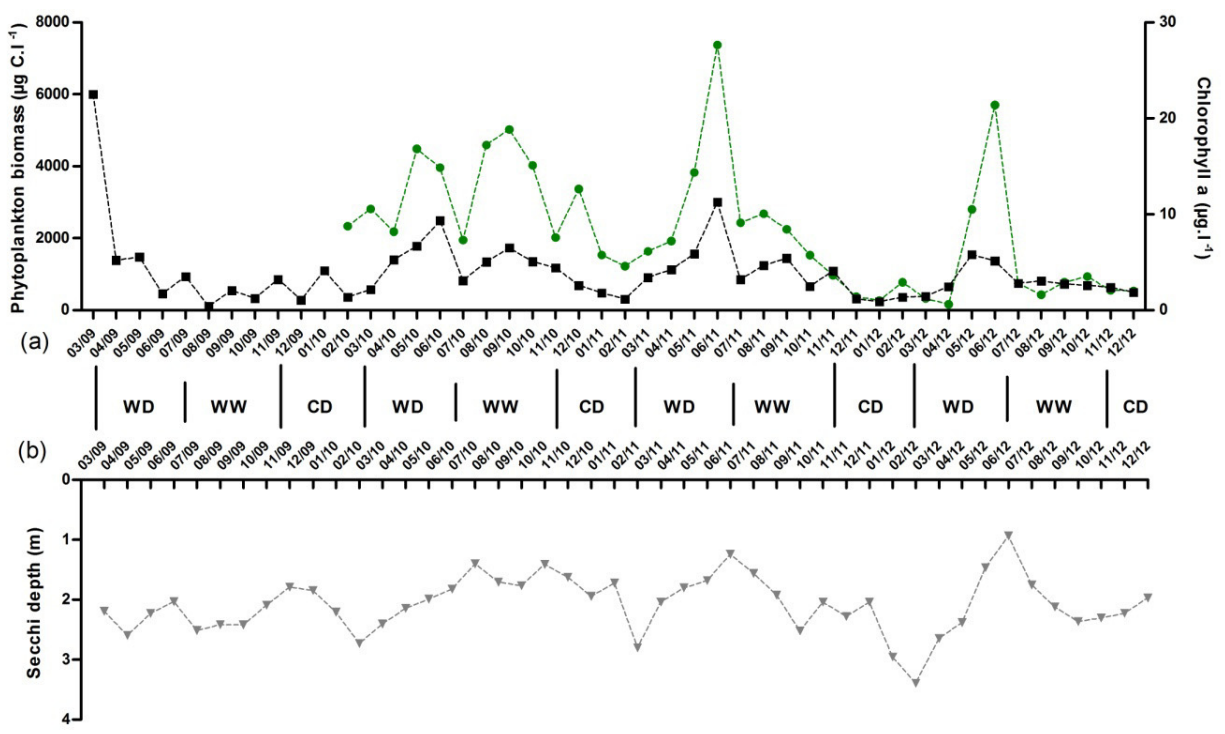

Fig. 3. (a) Monthly averages of the phytoplankton biomass (black square) and Chlorophyll a concentrations (green dot), (b) monthly averages values of Secchi depth measured at the five sampling sites (March 2009 - December 2012). CD: cool dry season; WD: warm dry season; WW: warm wet season. Fig. 3. (a) Moyennes mensuelles des biomasses phytoplanctoniques (carré noir) et des concentrations en Chlorophylle a (rond vert), (b) des profondeurs du disque de Secchi mesurés aux cinq stations de prélèvement (mars 2009 - décembre 2012). Valeurs exprimées durant la saison douce et sèche $(C D)$, la saison chaude et sèche (WD) et la saison humide (WW).

to meteorological and hydrological factors. The NT2 phytoplankton dynamic depends particulary on water level and temperature. Indeed, high phytoplankton total biomass and cellular concentrations are driven by higher temperature and low water level in the WD season. Conversely, low phytoplankton total biomass and cellular concentrations were probably due to high precipitation during the WW season. A transition period at the end of the WW season is defined by the low water level and high nitrate concentrations leading to increase of biomass. Then, high water level and low temperature are responsible for low biomass and cellular concentrations during the $\mathrm{CD}$ season.

\subsection{Phytoplankton metrics}

Chl-a values and phytoplankton biomass exhibited similar variations with higher values in WD season and at the end of the WW season (Fig. 2).

In March 2009, the phytoplankton biomasses reached the highest value with $6 \times 10^{3} \mu \mathrm{g} \mathrm{C.L}{ }^{-1}$ (Fig. 3a). Annual peaks of phytoplankton biomasses ranged between $1.4 \times 10^{3}$ and $3 \times 10^{3} \mu \mathrm{g} \mathrm{C.L} \mathrm{L}^{-1}$. Similarly to the biomass, two annual peaks of Chlorophyll a were generally observed (Fig. 3a). The first peak occurred between May and June whereas the second was recorded from August to October. The highest concentration was recorded in June 2011 with $27.6 \mu \mathrm{g} \mathrm{C.L}{ }^{-1}$. 
Table IV. $R^{2}$ (and p-values) for the correlation analyses between phytoplankton metrics and trophic state indicators. Significant results are in bold font used. Phyto Biomass = total phytoplankton biomass, $\mathrm{Chl} a=$ Chlorophyll $a$, TP $=$ total phosphorous, AARL-PC and AARL-PP scores.

Tableau IV. Résultats des tests de corrélation entre les métriques phytoplanctoniques et les indicateurs trophiques : valeurs du coefficient $R^{2}$ (et la valeur $p$ ). Les résultats significatifs sont en caractère gras. Phyto Biomass $=$ biomasse du phytoplankton total, $\mathrm{Chl} a=$ Chlorophylle $a, \mathrm{TP}=$ phosphore totaux, scores de AARL-PC et AARL-PP.

\begin{tabular}{|l|c|c|c|c|c|c|}
\hline Variables & $\begin{array}{c}\text { Phyto } \\
\text { Biomass }\end{array}$ & Chl $\mathbf{a}$ & TP & Secchi disk & AARL-PC & AARL-PP \\
\hline $\begin{array}{l}\text { Phyto } \\
\text { Biomass }\end{array}$ & - & $\mathbf{0 . 7 0 6 ( \mathbf { 0 . 0 0 0 2 ) }}$ & $-0.13(0.386)$ & $-\mathbf{0 . 4 5}(\mathbf{0 . 0 0 1 )}$ & $0.13(0.39)$ & $-0.11(0.46)$ \\
\hline Chl $\mathbf{a}$ & & - & $0.363(0.088)$ & $-0.002(0.99)$ & $0.35(0.09)$ & $0.04(0.85)$ \\
\hline TP & & & - & $0.202(0.25)$ & $-0.05(0.72)$ & $0.21(0.167)$ \\
\hline $\begin{array}{l}\text { Secchi } \\
\text { disk }\end{array}$ & & & & - & $-\mathbf{0 . 5 2 ( 0 . 0 0 0 2 )}$ & $0.17(0.27)$ \\
\hline AARL-PC & & & & & - & $0.29(0.052)$ \\
\hline AARL-PP & & & & & & - \\
\hline
\end{tabular}

Both Chl-a and phytoplankton biomass exhibited the lower values in mid-wet and cool seasons (respectively with values $<1.6 \mu \mathrm{g} \mathrm{C.} \mathrm{L}^{-1}$ and $<1 \times 10^{3} \mu \mathrm{g} \mathrm{C.L^{-1 }}$ ). They experienced a very significant correlation $(p<0.001)$ (Tab. III).

At the seasonal scale, the Secchi reached its deepest depth at the end of the $C D$ season with maximum value of $3.30 \mathrm{~m}$ measured in February 2012. Conversely, the shallowest depth was observed in June during a transition period between the WD and the WW seasons (Fig. 3b). Such variations correspond with phytoplankton dynamic; phytoplankton biomass having a strong relationship with the Secchi depth (Spearman $r=-0.45 ; p<0.01$ ) (Tab. III). According to TP concentrations (Tab. IV), higher values were measured during WW season after mixing period. Simultaneously the Secchi depth increase.

\subsection{Trophic status assessment and phytoplankton community}

From 2009 to 2012, the annual Chl-a concentrations, Secchi disk depth and TP values are presented in Table $V$. Trophic status categories resulting from application of OECD classification (1982) suggested that Chl-a classifies the NT2 Reservoir in an oligo-mesotrophic status between 2010 and 2012 although Chl-a may reach mesotrophic boundary especially in 2009. Secchi disk depth and TP values classify the NT2 Reservoir in a mesotrophic status (Tab. IV).

Although the results of the correlation tests on phytoplankton metrics versus physico-chemical parameters (TP, AARL-PC score) did not yield to significant relationship, the Secchi depth was significantly correlated with AARL-PC score (Spearman $r=-0.52 ; p<0.001$ ) 


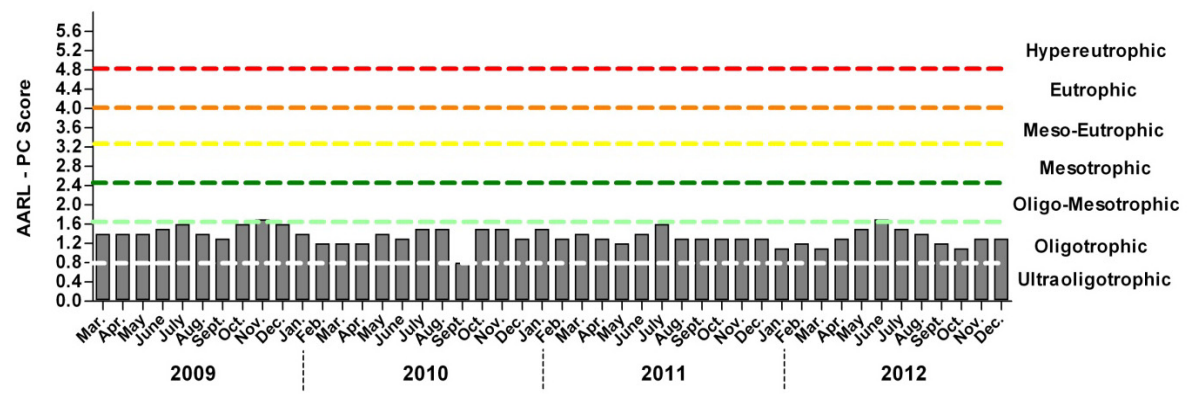

Fig. 4. The trophic status of the NT2 Reservoir according to the seven classes of trophic assessment by AARL-PC score (Peerapornpisal et al., 2004) based on six physico-chemical measurements at the sub-surface (DO, BOD, conductivity, $\mathrm{NO}_{3}-\mathrm{N}, \mathrm{NH}_{3}-\mathrm{N}$ and TP) (March 2009 - December 2012).

Fig. 4. Statut trophique du Réservoir NT2 selon les sept classes de niveau trophique de la méthode du score AARL-PC (Peerapornpisal et al., 2004) basée sur six mesures physiques et chimiques en sub-surface (DO, BOD, conductivité, $\mathrm{NO}_{3}-\mathrm{N}, \mathrm{NH}_{3}-\mathrm{N}$ et TP) (mars 2009 - décembre 2012).

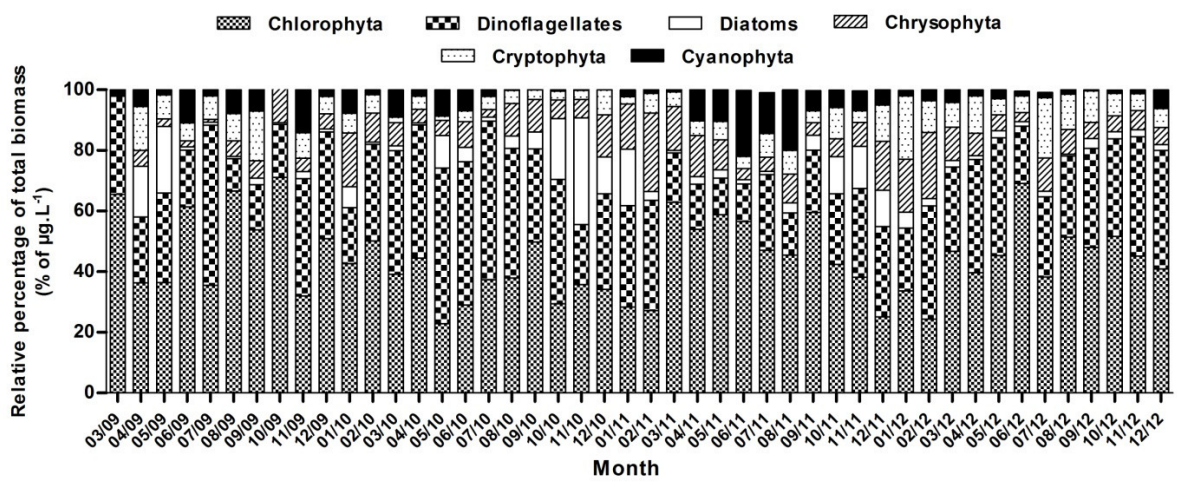

Fig. 5. Relative biomasses of the six phytoplankton classes identified within NT2 water samples $(n=5)$. Fig. 5. Biomasses relatives des six classes de phytoplancton identifiées dans les échantillons de NT2 $(n=5)$.

(Tab. III). The AARL-PC Score ranged between 0.7 and 1.7 over the study period (Fig. 4). Highest scores, reaching the oligo-mesotrophic status, were obtained punctually in November 2009 and June 2012, and the ultra-oligotrophic status was reached only in September 2010. It can therefore be concluded that the scores classified the NT2 Reservoir with an oligotrophic status during the whole study period.
Regarding the phytoplankton composition, 180 taxa were identified on the 222 samples collected over this study. Figure 5 shows the relative biomass of the NT2 phytoplankton community. Chlorophyta (green algae) and Dinoflagellates have dominated the assemblages. The main NT2 phytoplankton species with their associated scores used for AARL-PP calculation are shown in Table VI. The AARL-PP Score 
Table V. Annual means and ranges of values for total phosphorous concentrations, Chlorophyll a concentrations and Secchi disk depth measured at the five sampling sites $(2009-2012)$.

Tableau V. Moyennes annuelles des concentrations en phosphore totaux, en Chlorophylle a et des profondeurs du disque de Secchi mesurés aux cinq stations de prélèvement (2009 - 2012).

\begin{tabular}{|l|c|c|c|c|}
\hline $\begin{array}{l}\text { Variables } \\
\text { (Annual means) }\end{array}$ & 2009 & 2010 & 2011 & 2012 \\
\hline $\begin{array}{l}\text { Total phosphorous } \\
\left(\mathrm{mg}_{\mathrm{L}}{ }^{-1}\right)\end{array}$ & 0.03 & 0 & 0.02 & 0.13 \\
\hline $\begin{array}{l}\text { Chlorophyll } a \\
\left(\mu \mathrm{g} . \mathrm{L}^{-1}\right)\end{array}$ & No value & 12.5 & 8.7 & 4.3 \\
\hline Secchi depth $(\mathrm{m})$ & 2.15 & 2.00 & 2.00 & 2.25 \\
\hline
\end{tabular}

Table VI. Examples of the main NT2 phytoplankton species used for trophic status assessment according to AARL-PP score approach (Peerapornpisal et al., 2007).

Tableau VI. Exemple de notes des principales espèces phytoplanctoniques utilisées pour l'évaluation du niveau trophique selon la méthode du score AARL-PP (Peerapornpisal et al., 2007).

\begin{tabular}{|c|c|c|}
\hline $\begin{array}{c}\text { AARL-PP } \\
\text { score }\end{array}$ & $\begin{array}{c}\text { Phytoplankton species } \\
\text { Period of occurrence }\end{array}$ & Cool dry season \\
\hline $\mathbf{1}$ & $\begin{array}{c}\text { Dinobryon bavaricum, Dinobryon divergens, } \\
\text { Dinobryon sertularia }\end{array}$ & End of wet season \\
\hline $\mathbf{2}$ & $\begin{array}{c}\text { Cosmarium contractum var. minutum, Cyclotella } \\
\text { stelligera, Eunotia asterionelloides }\end{array}$ & $\begin{array}{c}\text { Warm dry and wet } \\
\text { seasons }\end{array}$ \\
\hline $\mathbf{3}$ & $\begin{array}{c}\text { Staurodesmus triangularis, Staurastrum sp., } \\
\text { Tetraedron caudatum, Elakatothrix gelatinosa }\end{array}$ & Botryococcus braunii \\
\hline $\mathbf{4}$ & $\begin{array}{c}\text { Chrophrocytium agardhianum } \\
\text { Wearm season }\end{array}$ \\
\hline $\mathbf{5}$ & Closterium limneticum, Peridinium inconspicuum \\
\hline $\mathbf{7}$ & $\begin{array}{c}\text { Ankistrodesmus bernardhii, Ankistrodesmus } \\
\text { spiralis, Monoraphidium arcuatum }\end{array}$ & $\begin{array}{c}\text { Cool and warm dry } \\
\text { season }\end{array}$ \\
\hline $\mathbf{8}$ & $\begin{array}{c}\text { Cryptomonas sp., Rhodomonas sp., Plagioselmis } \\
\text { nannoplanctica }\end{array}$ & Cool dry season \\
\hline $\mathbf{9}$ & Merismopedia tenuissima, Arthrospira fusiformis & $\begin{array}{c}\text { Cool and warm dry } \\
\text { season }\end{array}$ \\
\hline
\end{tabular}

ranged between highest score in WW season (AARL-PP score $=8$ ) and lowest ones at the beginning of WD season (AARL-PP score = 4) (Fig. 6). In 2009, the AARL-PP score indicated a mesoeutrophic status driven by the presence of Dinoflagellates in association with Cryptophyta (Cryptomonas sp. and 


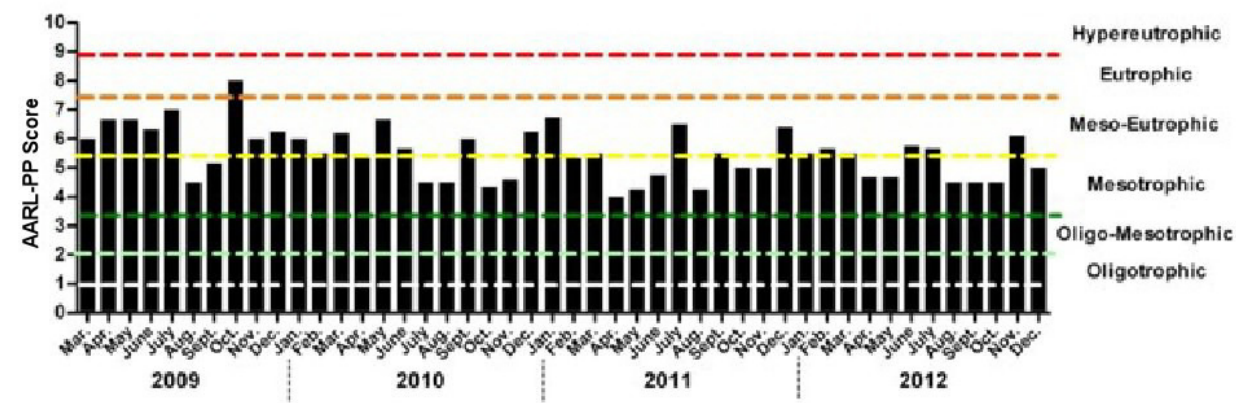

Fig. 6. The trophic status in Nam Theun 2 Reservoir by AARL-PP score (Peerapornpisal et al., 2007) regarding the NT2 phytoplankton composition from RES1 (March 2009 - December 2012).

Fig. 6. Niveau trophique du Réservoir Nam Theun 2 par le score AARL-PP (Peerapornpisal et al., 2007) en fonction de la composition phytoplanctonique de RES1 (mars 2009 - décembre 2012).

Plagioselmis nannoplanctica). Dinoflagellates highly contributed to the biomass with higher biovolume (mainly species belonging to Peridinium spp. and Ceratium hirundinella).

The species belonging to Cryptophyta were also found during the CD season and thus increased the trophic status during limited periods of time. These species were especially abundant early 2009 reaching $16 \%$ of relative biomass in April and in September. Since 2010, their contribution to the total biomass increased and reached a maximum of $20 \%$ in January and in July 2012.

Due to Chlorophyta taxa (including filamentous and Desmids), green algae reached more than $60 \%$ of the total biomasses regardless of the year or the month (Fig. 5) - e.g. Monoraphidium spp. Komárková-Legnerová, Ankistrodesmus spp. Corda, Tetraedron caudatum (Corda) Hansgrig, Closterium limneticum Lemmermann, Staurastrum sp. (Ralfs) Meyen, Staurodesmus Teiling. Since 2010 other dominant genera appeared into the assemblages with seasonal variations, such as those belonging to the group of Desmids. They generally occurred at the top of phytoplanktonic production from May to June. These algae confirm the mesotrophic status of the NT2 Reservoir during WD season.

A growth of diatoms was generally observed from October to January at the end of WW season. The relative percentage of diatoms reached a maximum of $35 \%$ of the total biomass in November 2010 (Cyclotellasp. Kützing, Eunotia sp. Ehrenberg, Urosolenia spp. Brightwell). They seem to contribute to the phytoplankton biomass at the end of WW season and to maintain the mesotrophic status. They are representative of assemblages from the end of WW season.

During CD season, Chrysophyta biomasses were high between December and March 2010/2011 and 2011/ 2012 reaching a maximum of $25 \%$ of the total biomasses in February 2011 (some species belonging to Dinobryon genera Ehrenberg with Dinobryon bavaricum Imhof, Dinobryon divergens Imhof and Dinobryon sertularia Ehrenberg). 
Table VII. Annual NT2 Reservoir trophic level from 2009 to 2012 according to trophic state indicators: the Chlorophyll a concentrations (Chl-a), physical and chemical parameters (Secchi values and AARL-PP score), the phytoplankton composition (AARL-PP score).

Tableau VII. Caractérisation du niveau trophique annuel du Réservoir de NT2 évalué pour les années comprises entre 2009 et 2012 en fonction de différents indicateurs : la concentration en Chlorophyll a (Chl-a), des valeurs du disque de Secchi et la composition phytoplanctonique (AARL-PP Score)

\begin{tabular}{|c|c|c|c|c|}
\hline Indicators & $\mathbf{2 0 0 9}$ & $\mathbf{2 0 1 0}$ & $\mathbf{2 0 1 1}$ & $\mathbf{2 0 1 2}$ \\
\hline ChI-a & - & Eutrophic & Mesotrophic & Mesotrophic \\
\hline Secchi & Eutrophic & Eutrophic & Eutrophic & Eutrophic \\
\hline AARL-PC & Oligo-mesotrophic & Oligotrophic & Oligotrophic & Oligotrophic \\
\hline AARL-PP & Meso-eutrophic & Mesotrophic & Mesotrophic & Mesotrophic \\
\hline
\end{tabular}

Cyanophyta developed mainly between April and August 2011 but remained low $(<10 \%)$ since the beginning of 2012. The main taxa did not show a cyanotoxic potential (Chroococcus sp. Nägeli, Merismopedia tenuissima Lemmermann and Arthrospira sp. (Gomont) Turpin). However, they remain an indicator for high trophic status. Annual trophic status (Tab. VII) seems to indicate that the NT2 Reservoir's trophic status evolved from mesotrophic (in 2009) to oligo-mesotrophic (from 2010 to 2012).

\section{DISCUSSION}

\section{Phytoplankton dynamic}

Temporal changes in the water column stability of the reservoir, related to physical characteristics (stratification vs. mixing) and meteorological variables, are one of the main environmental forces that affect phytoplankton dynamic (Harris, 1986; Henry, 1999; Dos Santos \& Calijuri, 1998; Han et al., 2000). The NT2 Reservoir was impounded during the WW season 2008. During the early stage of impoundment, the reservoir undergoes rapid and extensive fluctuations in flow and water levels (June and July 2009). As shown by Martinet et al. (2014), at the inter-annual scale, successions of phytoplankton could be explained by hydrological factors such as impoundment of the reservoir and spillage (results from dam site sampling at RES1). This previous study has shown that phytoplankton biomass declined during the period of rainfalls. This is also observed in the sampling sites located at the former riverbed with a decline of total biomass for the whole set of samples.

In 2010, with the beginning of NT2 Reservoir normal operation, the phytoplankton community exhibited intraannual variability. The assemblages became more complex and seasonal changes in the NT2 phytoplankton community were clearly demonstrated with the PCA. Over three distinct periods, the results underlined that the most relevant driving factors for phytoplankton community were the water temperature, the precipitations and the water level. Phytoplankton dynamic was framed in this seasonality following the hydrodynamic regime of the reservoir and the annual succession of mixing and stratification 
of the water column. Xiao et al. (2011) have shown similar trends at the Liuxihe Reservoir (China) located in another tropical system. At the annual scale, two peaks of phytoplankton biomass were detected occurring prior to and at the end of the WW season. The stratification period with high water temperature likely led to an increase of the phytoplankton biomass and Chl-a and shallow Secchi depth especially during the WD season. Such conditions might offer hydrological stability favouring phytoplanktonic production (León López et al., 2012).

Like other reservoirs (Harris \& Baxter, 1996; Calijuri et al., 2002), meteorological disturbances such as rainfalls also play a relevant role in the NT2 Reservoir dynamic of phytoplankton biomass. Therefore, its decline observed in July might be triggered by the strong rainfalls and the increase of reservoir water level. However, the unstable stratification period can lead to a diffusion of nutrients from impounded soils to upper layers while water temperature remains high. At the end of the WW season, higher nutrient concentrations might stimulate the NT2 Reservoir algal growth. This nutrient enrichment into the NT2 Reservoir can be expected during the rainfalls period due to soil leaching from the drawdown area and the tributaries of the catchment area (Oishi, 1996; Reynolds, 2006). Consequently, a second peak might appear at the end of WW season responding probably to $\mathrm{NO}_{3}{ }^{-}$input. These peaks were mainly composed by Diatoms species sensitive to stratification. They did not maintain their growth due to the mixing phase at the end of CD season.
Phytoplankton composition and trophic status assessment

Over the four studied years, the trophic status assessment of the reservoir has been performed following different methods. The significant correlation between phytoplankton biomass and Chl-a suggests that these two metrics could be appropriate to assess the trophic status of the NT2 Reservoir. Both Chl- $a$ and biomass generally experienced medium values, corresponding with an oligo-mesotrophic status. Highest values have been observed during the WD season. Similar tendency has been observed for physico-chemical features which classified the trophic status of the NT2 Reservoir as oligomesotrophic (Tab. VII).

The Secchi values indicate a trophic status higher than the classical Chl-a/ biomass based qualification. Its ranges of values remained shallow, corresponding to a meso-eutrophic status. Nevertheless, the total phytoplankton biomass has also a significant correlation with the Secchi depth suggesting that the water transparency might be dictated by phytoplankton biomass as Secchi values significantly respond to the biomass. The higher phytoplankton biomass might lead to a contraction of the euphotic zone at the WD season (Naselli Flores \& Barone, 1998). However, no clear relationship between Secchi depth, Chlorophyll $a$ or TP and trophic status could explain such low water transparency. This study confirms the results of Brazilian studies which revealed that many of the trophic status classification developed for temperate areas could not be applied to the tropics (Huszar et al., 1998). We can 
hypothesis that it could be likely more appropriate to minimize the interpretation of the Secchi values as its boundaries for eutrophic status according to OECD classification seem to be overexpressed the Secchi values.

The phytoplankton composition of NT2 Reservoir has been investigated in this study through AARL-PP approach for trophic status assessment. Although no correlation has been revealed between the tested indicators, phytoplankton community seem to reflect variations in the trophic status through the AARL-PP scores. For example, few months after the impoundment, the phytoplankton assemblages indicated the highest trophic status, by the presence of groups (e.g. Cryptomonas spp., Trachelomonas volvocina and Dinoflagellates) typically adapted to mixed and/or turbid environments (Reynolds et al., 2002; Padisák et al., 2009). The Dinoflagellates predominated throughout the study. In term of ecology, its perennial dominance has generally been reported in warm and stable epilimnion (Harris, 1986; Reynolds, 1997). They also have been found in a sub-tropical mesotrophic dam reservoir (Townsend \& Luong-Van, 1998; Townsend, 2001). In this study, Dinoflagellates did show a temporal pattern as its dominance mainly occurred during stratification periods. However, they sustained the phytoplankton biomass during low production period (CD season).

Change in phytoplankton assemblages from CD to WD seasons might explain variation in trophic status. For instance, trophic level decreased since Desmids appeared in the assemblages in 2010 . They are generally more common and diverse in oligotrophic lakes and ponds (Gerrath, 1993). Furthermore, similar assemblages have been recorded in the Nam Ngum Reservoir (Lao PDR), reflecting an oligo-mesotrophic status (Malaiwan \& Peerapornpisal, 2009; Chanudet et al., 2011).

It appears that the phytoplankton community, Chl $a$ and Secchi depth are suitable metrics for a young sub-tropical reservoir monitoring as NT2. They illustrated a seasonality defined by four well distinguishable periods: (i) a phase where the water is clear observed during the CD season, (ii) a stable stratification period with green algae development involving shallow Secchi depth during the WD season, (iii) a decrease of the phytoplankton metrics at the top of WW season and (iv) a diatoms development at the end of the WW season. Thanks to the knowledge of these distinct periods, we can manage to find the appropriate sampling frequency selecting the number of samplings per year. Like for European and North American lakes and reservoirs, three campaigns during phytoplankton production period are recognized to get a representative vision of trophic reservoir status. To assess NT2 reservoir trophic state evolution, it is then recommended to focus on the period between the WD and WW seasons for the NT2 trophic assessment.

\section{CONCLUSION}

This study provides a comprehensive description of the phytoplankton community in the NT2 Reservoir. A total of 180 taxa were recorded over the period of study. Among them, Dinoflagellates dominated the phytoplankton 
community since the impoundment. Its colonisation capacity in a new environment and its mixotrophic characteristics make them well adapted to the NT2 Reservoir environment. Two years after impoundment, the NT2 phytoplankton biomass showed significant seasonal changes. These changes were driven by environmental variables (water temperature, precipitation) and hydrological factors (water level fluctuation). Then, the response of the phytoplankton community to environmental changes suggests the utility of the phytoplankton as a monitoring tool of the water quality assessment of young sub-tropical reservoirs.

This study also revealed the suitability of Chl-a, phytoplankton biomass and phytoplankton composition for assessing the trophic state of the NT2 Reservoir in accordance with the OECD classification and Peerapornpisal indices (AARL-PC and AARL-PP). During the early stages after impoundment, the NT2 Reservoir showed characteristics of higher trophic status. However, the NT2 Reservoir trophic state might still be far from equilibrium reflected by an oligotrophication at the end of period of study. Other tropical reservoirs have shown a stabilization of their trophic status after at least 10 years (Straškraba \& Tundisi, 2000). It is thus proposed to carry on using this multi-indicator approach to adequately assess the NT2 trophic status evolution in the future water quality monitoring, with a particular focus on the production period.

\section{ACKNOWLEDGEMENT}

This research has been conducted at the Aquatic Environment Laboratory of Nam Theun 2 Power Company in Lao PDR whose Shareholders are Électricité de France, Lao Holding State Enterprise and Electricity Generating Public Company Limited of Thailand.

The authors would like to thank everyone who contributed to the NT2 monitoring programme, especially to the Nam Theun 2 Power Company (NTPC) and Electricity of France (EDF) for providing financial and scientific support. We are grateful to the management and staff of the Aquatic Environment Laboratory especially Ms Maud Cottet, Team Leader of the Hydrobiology section of the $A E$ Lab, as well as the Logistics Dept. for its constant support. We also would like to thank Frederic RIMET (INRA Thonon les Bains - France) for his help for the species identification. We finally would like to thank Mr Paul Dumbrell who reviewed this version of the manuscript as a native English speaker.

\section{REFERENCES}

AFNOR, 2006. EN 15204 - Water quality Guidance standard on the enumeration of phytoplankton using inverted microscopy (Utermöhl technique). Afnor: 1-39.

American Public Health Association (APHA), 1995. Standard Methods for Examination of Water and Wastewater, 19th ed. APHA, Washington DC, USA.

American Society of Limnology and Oceanography (ASLO), 1990. Large-scale variability and interactions among phytoplankton, bacterioplankton, and phosphorus. Limnol. Oceanogr. 35(7) : 14371455.

Anneville O., Kaiblinger C., Tadonléké R., Druart J.-C. \& Dokulil M.T., 2008. Contribution of long-term monitoring to the 
European Water Framework Directive implementation. In: Sengupta M. \& Dalwani R. (Eds.), The 12th World Lake Conference, Ministry of Environment \& Forests, New Delhi, India, 1122-1131.

Becker V., Caputo L., Ordõnez J., Marce R., Armengol J., Crossetti L.O. \& Huszar V.L.M., 2010. Driving factors of the phytoplankton functional groups in a deep Mediterranean reservoir. Water Res. 44 : 3345-3354.

Bourrelly, 1981. Les algues d'eau douce : Les algues jaunes et brunes. In: Boubée N. (Ed.), Paris.

Bourrelly, 1985. Les algues d'eau douce : Les algues bleues et rouges. In: Boubée N. (Ed.), Paris.

Bourrelly, 1990. Les algues d'eau douce: Les algues vertes. In: Boubée N. (Ed.), Paris.

Brettum, 1989. Alger som indicator pa vannkvalitet i norske innsjøer, Planteplankton, NIVA, Trondheim, Norway.

Büsing N., 1998. Seasonality of phytoplankton as an indicator of trophic status of the large perialpine 'Lago di Garda'. Hydrobiologia 369/370 : 153-162.

Calijuri M.C. \& Dos Santos A.C.A., 2001. Temporal variations in phytoplankton primary production in a tropical reservoir (Barra Bonita, SP - Brazil). Hydrobiologia 445 : 11-26.

Calijuri M.C., Dos Santos A.C.A. \& Jati S., 2002. Temporal changes in the phytoplankton community in the Barra Bonita reservoir (São Paulo, Brazil). Hydrobiologia 24 : 617-634.

Catalan J., Ventura M., Munné A. \& Godé L., 2003. Desenvolupament d'un index integral de qualitat ecologica i regionalitzacio ambiental dels sistemes lacustres de Catalunya, Agencia Catalana del Aigua, Generalitat de Catalunya, Spain.

Chanudet V., Descloux S., Harby A., Sundt H., Hansen B.H., Brakstad O., Serca D.
\& Guerin F., 2011. Gross $\mathrm{CO} 2$ and $\mathrm{CH} 4$ emissions from the Nam Ngum and Nam Leuk sub-tropical reservoirs in Lao PDR. Science of the Total Environment 409 : 5382-5391.

Chanudet V., Fabre V. \& Van Der Kaaij T., 2012. Application of a three-dimensional hydrodynamic model to the Nam Theun 2 Reservoir (Lao PDR). J. Great Lakes Res. 38 : 260-269.

Chanudet V., Smits J., Van Beek J., Boderie P., Guérin F., Serça D., Deshmukh C. \& Descloux S. Hydrodynamic and water quality 3D modelling of the Nam Theun 2 Reservoir (Lao PDR): predictions and results of scenarios related to reservoir management, hydrometeorology and nutrient input. Hydroécol. Appl. 19 (same issue).

Codd G.A., Lindsay J., Young F.M., Morrison L.F. \& Metcalf J., 2005. From mass mortalities to management measures. In: Huisman J., Matthijs H.C.P. \& Visser P.M. (Eds.), Harmful Cyanobacteria 1-23.

Crossetti L.O. \& Bicudo C.E.M., 2005. Structural and functional phytoplankton responses to nutrient impoverishment in mesocosms placed in a shallow eutrophic reservoir (Garcas Pond), Sao Paulo, Brazil. Hydrobiologia 541: 71-85.

Crossetti L.O. \& Bicudo C.E.M., 2008. Phytoplankton as a monitoring tool in a tropical urban shallow reservoir (Garças Pond): the assemblage index application. Hydrobiologia 610 : 161-173.

Dai H., Zheng T. \& Liu D., 2010. Effects of Reservoir Impounding on Key Ecological Factors in the Three Gorges Region. Procedia Environ. Sci. 2 : 15-24.

Descloux S., Guédant P., Phommachanh D. \& Luthi R. Main features of the Nam Theun 2 hydroelectric project (Lao PDR) and the associated environmental monitoring programs. Hydroécol. Appl. 19 (same issue).

Díaz-Pardo E., Vazquez G. \& López-López E., 1998. The phytoplankton community 
as a bioindicator of health conditions of Atezca Lake, Mexico. Aquat. Ecosyst. Health Manag. 3 : 257-266.

Dos Santos A.C.A \& Calijuri M.C. 1998 Survival strategies of some species of the phytoplankton community in the Barra Bonita reservoir (São Paulo, Brazil). Hydrobiologia, 367: 139-152.

European Community Parliament and Council, 2000 - Directive of the European Parliament and ofthe Council 200/ 60/EC establishing a framework for community action in the field of water policy. European Commission PECONS 3639/1/100. Rev 1, Luxembourg.

Feinpend L., Zhang H., Zhu Y., Xiao Y. \& Chen L., 2013. Effect of flow velocity on phytoplankton biomass and composition in a freshwater lake. Science of the Total Environment 447 : 64-71.

Gerrath J.F., 1993. The biology of Desmids: a decade of progress. In: Round F.E. \& Chapman D.J. (Eds.), Progress in phycological research, Bristol, 79-192.

Han B.P., Armengol J., Garcia J.C., Comerma M., Roura M., Dolz J. \& Straskraba M., 2000. The thermal structure of Sau Reservoir (NE: Spain): a simulation approach. Ecol. Model. 125 : 109-122.

Happey-Wood C.M., 1988. Ecology of freshwater planktonic green algae. In: Sandgren C.D. (Ed.), Growth and Reproductive Strategies of Freshwater Phytoplankton, Cambridge University Press, Cambridge 175-226.

Harris G.P., 1986. Phytoplankton Ecology: Structure, Function and Fluctuation. Chapman and Hall, New York, 384 p.

Harris G.P. \& Baxter G., 1996. Interannual variability in phytoplankton biomass and species composition in a subtropical reservoir. Freshwater Biology 35 : 545560.

Henry R., 1999. Heat budgets, thermal structure and dissolved oxygen in
Brazilian reservoirs. In: Tundisi J.G. \& Straskraba M. (Eds.), Theoretical reservoir ecology and its applications. International Institute of Ecology, Backhuys Publishers, São Carlos, 125-151.

Hillebrand H., Dürselen C.D., Kirschtel D., Pollingher U. \& Zohary T., 1999. Biovolume calculation for pelgic and benthic microalgae. J. Phycol. 35 : 403-424.

Hindák, 1984. Studies on chlorococcal algae (Chlorophyceae) III. Biologicke Práce, Veda, Bratislava.

Hindák, 1988. Studies on chlorococcal algae (Chlorophyceae) IV. Biologicke Práce, Veda, Bratislava.

Hindák, 1990. Studies on chlorococcal algae (Chlorophyceae) V. Biologicke Práce, Veda, Bratislava.

Huszar V.L.M., Silva L.H.S., Domingos P., Marinho M. \& Melo S., 1998. Phytoplankton species composition is more sensitive than OECD criteria to the trophic status of three Brazilian tropical lakes. Hydrobiologia : 59-71.

León López N., Rivera Rondón C.A., Zapata Á., Jimenez J., Villamil W., Arenas G., Rincón C. \& Sánchez T., 2012. Factors controlling phytoplankton in tropical high-mountain drinking-water reservoirs. Limnetica 31(2) : 305-322.

Lewis W.M.J., 2000. Basis for the protection and management of tropical lakes. Lakes and Reservoirs: Res. Manage. 5 : 35-48.

Malaiwan T. \& Peerapornpisal Y., 2009. Diversity of phytoplankton and water quality in the reservoir of Nam Ngum dam, Lao PDR. KKU Sci. J. (Suppl.) 37 : 42-49.

Martinet J., Descloux S., Guédant P. \& Rimet F., 2014. Phytoplankton functional groups for ecological assessment in young sub-tropical reservoirs: case study of the Nam-Theun 2 Reservoir (Lao PDR, South-East Asia). J. Limno. 73(3) : 536-550. 
Melo S. \& Huszar V.L.M., 2000. Phytoplankton in an Amazonian flood plain lake (lago Batata, Brasil): diel variation and species strategies. J. Plankton Res. 22 : 63-76.

Molina Navarro E., Martinez-Perez S., Sastre-Merlin A., Verdugo-Althlöfer M. \& Padisák J., 2014. Phytoplankton and suitability of derived metrics for assessing the ecological status in a limno-reservoir, a Water Framework Directive nondefined type of Mediterranean waterbody. Lake Reserv. Manage. 30 : 46-62.

Naselli Flores L., 2000. Phytoplankton assemblage in twenty-one Sicilian reservoirs: relationships between species composition and environmental factors. Hydrobiologia $424: 1-11$.

Naselli Flores L. \& Barone R., 1998. Phytoplankton dynamics in two reservoirs with different trophic state (Lake Rosamarina and Lake Arancio, Sicily, Italy). Hydrobiologia 163-178.

OECD, 1982. Eutrophication of waters, monitoring, assessment and control. Organization of Economic Cooperation and Development, Paris, France.

Oishi M.K., 1996. Caracterização do meio físico, das características físicas e químicas e do fluxo de nutrientes em tributários da bacia hidrográfica do reservatório de Barra Bonita (Médio Tietê, SP), São Carlos, Brazil, 199 p.

PadisákJ., 2003. Phytoplankton. In: O'Sullivan P.E. \& Reynolds C.S. (Eds.), The Lakes Handbook 1. Li mnology and Limnetic Ecology. Blackwell Science Ltd., Oxford, 251-308.

PadisákJ., Borics G., Grigorskzky l., SoróczkiPintér É., 2006. Use of phytoplankton assemblages for monitoring ecological status of lakes within the Water Framework Directive: the assemblage index. Hydrobiologia 502 : 157-168.

Padisák J., Crossetti L.O. \& Naselli-Flores L., 2009. Use and misuse in the application of the phytoplankton functional classification: a critical review with updates. Hydrobiologia 621 : 1-19.

Peerapornpisal Y., Chaiubol C., Pekkoh J., Kraibut H., Chorum M., Wannathong P., Ngernpat N., Jusakul K., Thammathiwat A., Chuananta J. \& Inthasotti T., 2004. The monitoring of water quality in ang kaew reservior of Chaing Mai University by using phytoplankton as bioindicator from 1995-2002. Chiang Mai J. Sci. 31(1) : 85-94.

Peerapornpisal Y., Pekkoh J., Powangprasit J., Tonkhamdee T., Hongsirichat A. \& Kunpradid T., 2007. Assessment of water quality in standing water by using dominant phytoplankton (AARL - PP Score). J. Fish. Tech. Res. 1(1) : 71-81.

Poikane S., 2009. Lakes. In: Water Framework Directive intercalibration technical report. Office for Official Publications of the European Communities, Luxembourg.

Poikane S., Van der Berg M., Hellsten S., de Hoyos C., Ortiz-Casas J., Pall K., Portielje R., Phillips G., Solheim A.L., Tierney D., Wolfram G. \& Van de Bund W., 2011. Lake ecological assessment systems and intercalibration for the European Water Framework Directive: aims, achievements and further challenges. Pro. Env. 9 : 153-168.

Reynolds C.S., 1984. The ecology of freshwater plankton. Cambridge University Press, New York, USA.

Reynolds C.S., 1997. Vegetation Processes in the Pelagic: A Model for Ecosystem Theory. Ecology Institute, Oldendorf/ Luhe, Germany.

Reynolds C.S., 1998. What factors influence the species composition of phytoplankton in lakes of different trophic status. Hydrobiologia 369-370 : 11-26.

Reynolds C.S., 2006. The ecology of phytoplankton. Cambridge University Press, London, 4, $535 \mathrm{p}$. 
Reynolds C.S., Huszar V.L.M., Kruk C., Nasseli-Flores L. \& Melo S., 2002. Towards a functional classification of the freshwater phytoplankton. J. Plankton Res. 24 : 417-428.

Rigosi A. \& Rueda J.F., 2012. Hydraulic control of short-term successional changes in the phytoplankton assemblage in stratified reservoirs. Ecol. Eng. 44 : 216-226.

Salmaso N., Morabito G., Buzzi F., Garibaldi L., Simona M. \& Mosello R., 2006. Phytoplankton as an indicator of the water quality of the deep lakes south of the Alps. Hydrobiologia 563 : 167-187.

Sarmento H. \& Descy J.-P., 2008. Use of marker pigments and functional groups for assessing the status of phytoplankton assemblages in lakes. J. Appl. Phycol. 20 : 1001-1011.

Sarmento H., Unrein F., Isumbisho M., Stenuite S., Gasol J.M. \& Descy J.P., 2008. Abundance and distribution of picoplankton in tropical, oligotrophic Lake Kivu, eastern Africa. Freshw. Biol. 53 : 756-771.

Smith V.H., 1983. Low nitrogen to phosphorus ratios favour dominance by bluegreen algae in lake phytoplankton. Science 221 : 669-671.

Starmach, 1972. Chlorophyta III. Flora Słodkowodna Polski, In: Starmach K. (Ed.), Polska Akademia Nauk, Instytut botaniki. Państwowe Wydawnictwo Naukowe, Warszawa - Kraków, 10.

Starmach, 1974. Cryptophycea Dinophycea Raphidophycea. Flora Słodkowodna Polski, In: Starmach K. (Ed.), Polska Akademia Nauk, Instytut botaniki. Państwowe Wydawnictwo Naukowe, Warszawa - Kraków, 4.

Starmach, 1983. Euglenophyta. Flora Słodkowodna Polski, In: Starmach K. (Ed.), Polska Akademia Nauk, Instytut botaniki. Państwowe Wydawnictwo Naukowe, Warszawa - Kraków, 3.

Straškraba M. \& Tundisi J.G., 2000. Diretrizes para o gerenciamento de lagos: gerenciamento da qualidade da água de represas, São Carlos, 258 p.

Thornthon K.W., Kimmel B.L. \& Payne F.E., 1990. Reservoir Limnology: ecological perspectives. Wiley-interscience Publications, New York, 246 p.

Townsend S.A., 2001. Perennial domination of phytoplankton by Botryococcus and Peridinium in a discontinuously polymictic reservoir (tropical Australia). Archiv Fur Hydrobiologie 151 : 529-548.

Townsend S.A. \& Luong-Van J.T., 1998. Phytoplankton biomass and composition in Manton River Reservoir, a mesotrophic impoundment in the Australian wet/dry tropics. Int. Rev. Hydrobiol. 83 : 113-120.

Tundisi J.G., Matsumura-Tundisi T. \& Rocha O., 1999. Theoretical basis for reservoir management. In:Tundisi J.G. \& Straskraba M. (Eds.), Theoritical Reservoir Ecology and its Applications. International Institute of Ecology, Brazilian Academy of Sciences and Backhuys Publishers, São Carlos, 505-528.

Utermöhl H., 1958. Zur Vervolkomnung der quantitativen Phytoplankton: Methodik. Mit. Int. Ver. Theor. Angew. Limnol. 9 : 1-38.

Vollenweider R.A., 1969. A manual on methods for measuring primary production in aquatic environments. Blackwell Scientific Publications, Philadelphia, $213 \mathrm{p}$.

Wetzel R.G., 2001. Limnology: Lake and River Ecosystems, Academic Press, San Diego, 1006 p.

Wetzel R.G. \& Lickens G.E., 2000. Limnological Analyses, 3rd ed. Springer Science and Business Media. 
Xiao L.J., Wang T., Hu R., Han B.P., Wang S., Qian X. \& Padisák J., 2011. Succession of phytoplankton functional groups regulated by monsoonal hydrology in a large canyon-shaped reservoir. Water Res. 45 : 5099-5109.

Zeng H., Song L., Yu Z. \& Chen H., 2006. Distribution of phytoplankton in the
Three-Gorge Reservoir during rainy and dry seasons. Sci. Total Environ. 367 : 999-1009.

Zhu K., Bi Y. \& Hu Z., 2013. Responses of phytoplankton functional groups to the hydrologic regime in the Daning River, a tributary of Three Gorges Reservoir, China. Sci. Total Environ. 450-451 : 169-177. 